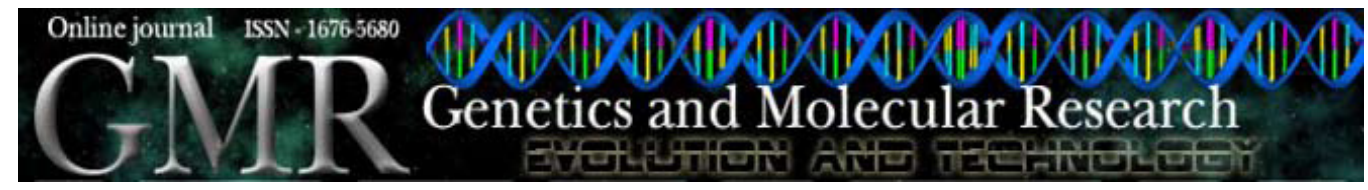

\title{
Brazilian Nelore cattle: a melting pot unfolded by molecular genetics
}

\author{
M.A.C. Dani ${ }^{1}$, M.B. Heinneman ${ }^{2}$ and S.U. Dani ${ }^{1}$ \\ ${ }^{1}$ Excegen Genetica S.A., Acangaú Valley, Paracatu, MG, Brasil \\ ${ }^{2}$ Departamento de Medicina Veterinária Preventiva, \\ Escola de Veterinária, Universidade Federal de Minas Gerais, \\ Belo Horizonte, MG, Brasil \\ Corresponding author: M.A.C. Dani \\ E-mail: macdani@hotmail.com
}

Genet. Mol. Res. 7 (4): 1127-1137 (2008)

Received July 22, 2008

Accepted August 16, 2008

Published October 21, 2008

\begin{abstract}
The aim of the present article was to study the population structure and genetic diversity of Nelore cattle and genetic relationships between Nelore and different taurine and zebu breeds raised in Brazil. DNA polymorphism analysis was carried out with 1976 animals of 16 zebu, taurine and synthetic breeds raised in Brazil. A higher genetic differentiation was observed in taurine than in zebu cattle. Gene flow was intense between the different zebu populations. Genetic affinity analysis within the most conspicuous Brazilian zebu beef cattle, the Nelore, was carried out in a group of 615 animals from 15 representative herds. This analysis revealed at least two major Nelore subtypes, named after some genotype-phenotype associations such as the "thrifty type" and the "demanding type". This study provides molecular genetic evidence that, despite selection based on the phenotype, gene flow and gene segregation still play a major role in maintaining genetic variability within the Nelore and zebu population as a whole in Brazil.
\end{abstract}

Key words: Bos indicus; Bos taurus; DNA marker; Microsatellite; Marker-assisted selection; Nelore 


\section{INTRODUCTION}

Brazil has the world's largest commercial cattle herd, which is estimated at some 200 million head (IBGE, 2005). Most of these cattle have an Indian, humped, zebu cattle (Bos indicus) ancestry, although the zebu was not the first cattle to be introduced in Brazil. The first taurine, humpless cattle (Bos taurus) from Portugal and Spain were introduced in Brazil from the early 16th century (Jaeger, 1943) to the late 18th century (Rouse, 1977; Salazar and Cardozo, 1986). From 1850 to 1910, British breeds were imported, followed by other continental breeds, and then by zebu cattle from India. Several importations of diverse zebu cattle from India took place throughout the 19th and 20th centuries (Santiago, 1985).

Since zebu cattle and crossings thereof proved to be highly adapted to the more exacting Brazilian ecological settings than European cattle did, it is generally accepted that the genetic structure of Brazilian cattle is highly influenced by that of zebu cattle. Traditionally, Brazilian breeders employed mostly phenotype-based cross-breeding strategies to improve the adaptability and productivity of their herds. It was only in the late 1940 s and early 1950s that the principles and techniques of quantitative genetics began to be applied in the selection of beef and dairy cattle in Brazil (Carneiro and Lush, 1948; Villares, 1950; Carneiro, 1954; Memória, 1954; Carneiro and Memória, 1959; Tundisi et al., 1965/1966).

The genetic improvement of cattle in Brazil frequently involved crossings between zebu and taurine cattle, but also crossings between different zebu cattle. Although it is generally assumed that gene flow between and within zebu and taurine cattle and crosses thereof have been intense in Brazil, there is a lack of information on gene flow quantification and breed relationships among Brazilian cattle. Miretti et al. (2002) did not find any zebu mtDNA haplotype in taurine cattle breeds descendant from cattle that were introduced in South America some 500 years ago by Portuguese and Spanish colonizers. Yet, Meirelles et al. (1999) found taurine mtDNA in 59 of 102 samples of Gir and Nelore breeds, which was consistent with the known matrilinear contribution of the taurine cattle originally introduced in Brazil, for the formation of the modern Brazilian zebu. A comprehensive study of the genetic structure and diversity of some commercial cattle breeds in Brazil, as related to some Creole Brazilian breeds, was performed by Egito and co-workers (2007). Their genetic data corroborate historical records in that they indicate that variable patterns of breed admixture have occurred since colonial times shaping the current genetic status of the local breeds.

Yet, there are many gaps in the knowledge of the genetic diversity and population structure of zebu cattle in Brazil, and even more so when it relates to the most conspicuous Brazilian beef breed, the Nelore breed. Little is known about the genetic origins of Brazilian Nelore and its relationships to other zebu and taurine cattle. The literature on this issue is sometimes confusing and misleading. For example, Machado et al. (2003) carried out a genetic study with 18 zebu sires (Nelore, Gir and Guzerat) and 18 Holstein sires using a set of 9 microsatellite markers and found that Guzerat and Nelore sires were more closely related to each other than with Gir sires. Yet, Kemenes et al. (1999), studying genetic distances in Brazilian zebu and taurine cattle by means of $\kappa$-casein, $\beta$-lactoglobulin and growth hormone allele frequencies, found that Guzerat and Gir were more similar to each other than to Nelore. Cervini et al. (2006) performed microsatellite genotypings of 200 unrelated adult Nelore cattle 
from different regions of Brazil, to assess variability and exclusion probability parameters. Although this study can be useful for parentage testing within the Nelore group, it did not enhance our knowledge of the genetic affinities among different groups of Nelore cattle.

The aims of the present article were to study a much larger and diverse series of animals to determine the gene flow between different Brazilian taurine and zebu populations and to evaluate the genetic structure and breed relationships within the more conspicuous Nelore population, as compared to other zebu, taurine and synthetic cattle raised in Brazil.

Microsatellites were used as markers in this study because they are abundant in the genome; they are highly polymorphic, even in endogamic populations, and they are co-dominants. Microsatellites offer great potential for genetic comparisons within and between populations; their random distribution within the genome and their high level of polymorphism have greatly facilitated the construction of genetic maps of pig, cattle, human, and chicken genomes (Hazan et al., 1992; Bishop et al., 1994; Archibald et al., 1995; Cheng et al., 1995), the analysis of mating systems and population structures (Bruford and Wayne, 1993; GlowatzkiMullis et al., 1995), and the reconstruction of phylogenetic relationships among populations in humans, sheep and cattle (Bowcock et al., 1994; Forbes et al., 1995; MacHugh et al., 1994, 1997). They are also used as a tool for forensic studies (Jeffreys et al., 1992).

\section{MATERIAL AND METHODS}

\section{Animals}

All animals used in this study were regarded as "purebred", since they were all registered in their respective breeder's association (animal registry in any Brazilian breeder association is made solely on the basis of the compliance of the animal with a standard phenotype). For population pairwise gene flow and Fst analyses, we took at random genotypic data of Nelore (NE; $N=1578)$, Polled Nelore (NO; $N=85)$, Brahman $(\mathrm{N}=205)$, Gir $(\mathrm{N}=256)$, Guzerat $(\mathrm{N}=66)$, Indo-Brazilian $(\mathrm{N}=156)$, Sindhi $(\mathrm{N}=65)$, Holstein $(\mathrm{N}=79)$, Jersey $(\mathrm{N}=$ $21)$, and Caracu $(\mathrm{N}=18)$. For the genetic affinity analyses we took animals from the following zebu, taurine and synthetic breeds: Angus $(\mathrm{N}=10)$, Brahman $(\mathrm{N}=205)$, Gir $(\mathrm{N}=256)$, Guzerat $(\mathrm{N}=66)$, Indo-Brazilian $(\mathrm{N}=156)$, Sindhi $(\mathrm{N}=65)$, Holstein $(\mathrm{N}=79)$, Senepol $(\mathrm{N}=$ 13), Charolais $(\mathrm{N}=10)$, Curraleiro $(\mathrm{N}=3)$, Santa Gertrudis $(\mathrm{N}=4)$, Jersey $(\mathrm{N}=21)$, Caracu $(\mathrm{N}=18)$, Girolanda $(\mathrm{N}=17)$, Tabapuã $(\mathrm{N}=5)$, and $\mathrm{NE} / \mathrm{NO}(\mathrm{N}=615)$. In the latter analysis, only a cohort of 615 animals were taken from the general Nelore population used in the former analysis; this cohort comprised animals from 15 Nelore herds (NE1 to NE15) representative of the genetic diversity and distinct geographic origins of the Brazilian Nelore.

\section{Genotyping}

Genotyping of microsatellite loci was performed at Excegen's Laboratory of Molecular Genetics. DNA from hair, blood, nasal swab, or sperm were extracted using the DNA IQ System (Promega, USA) and samples were typed for the 9 microsatellite loci of the international marker set for parentage testing recommended by ISAG: BM1824, BM2113, ETH10, ETH225, INRA23, SPS115, TGLA122, TGLA126, TGLA227. Multiplex PCR was set up with Promega's STR 10X Buffer (1X); 1-4 pmol of each forward primer (labeled with one 
of the three fluorophores - FAM, HEX or TAMRA) and reverse primer (unlabeled); 0.5 unit Platinum Taq DNA polymerase ${ }^{\circledR}$ (Invitrogen, USA) and 50-100 ng genomic DNA, in a 12.5$\mu \mathrm{L}$ total reaction volume. Reactions were carried out in a Mastercycler PCR Thermocycler (Eppendorf, Germany) under the following conditions: hot start at $94^{\circ} \mathrm{C}$ for $4 \mathrm{~min} ; 30$ cycles of $94^{\circ} \mathrm{C}$ for $1 \mathrm{~min}, 58^{\circ} \mathrm{C}$ for $1 \mathrm{~min}$ and $72^{\circ} \mathrm{C}$ for $1 \mathrm{~min}$, and a final extension at $72^{\circ} \mathrm{C}$ for $4 \mathrm{~min}$. PCR products were diluted (1:20), mixed with ET400 (GE Healthcare, USA) according to manufacturer instructions and analyzed in the MegaBACE 1000 DNA Sequencer (GE Healthcare, USA). Allele sizes were scored using Fragment Profiler 1.2 (GE Healthcare, USA) and were numerically defined according to the ISAG/2005-2006 cattle comparison test.

\section{Statistical analysis}

To get an insight of the genetic structure of Nelore as compared to other zebu and taurine breeds, population pairwise analyses were performed with the following breeds: Brahman, Caracu, Gir, Guzerat, Holstein, Indo-Brazilian, Jersey, Nelore, Polled Nelore, and Sindhi. Allele frequencies, mean number of alleles per locus, gene diversity, observed heterozygosity (He), and polymorphism information content (PIC) were calculated using the Microsatellite Tools for Excel ${ }^{\circledR}$ (Microsoft Corporation, USA). Genetic distance, F-statistics and dendrogram construction were performed using the POPGENE 1.31 program (Yeh and Boyle, 1997).

\section{RESULTS}

Population pairwise analysis of Fst and gene flow $(\mathrm{Nm})$ parameters of zebu and taurine cattle are shown in Table 1. Global Fst and Nm values were 0.1418 and 1.4820 , respectively. Fst and Nm values were 0.1064 and 2.0992 for zebu and 0.0624 and 3.7581 for taurine cattle, respectively. Mean Fst and mean Nm were 0.0372 and 7.491 for zebu and 0.0819 and 3.025 for taurine cattle, respectively. Among zebu cattle, extreme Fst and Nm values were 0.0135 and 18.2639 for Nelore x polled Nelore, and 0.0175 and 14.0553 for Brahman x Guzerat, respectively. Among taurine cattle, extreme Fst and Nm values were 0.0578 and 4.0718 for Holstein x Caracu, respectively.

\begin{tabular}{l} 
Table 1. Genetic structure of the cattle population, as assessed by pairwise Fst (genetic differentiation between \\
herds or breeds, below diagonal) and Nm (gene flow, above diagonal). \\
\begin{tabular}{lccccccccccc}
\hline \\
\hline
\end{tabular} \\
\hline
\end{tabular}

BR, Brahman; CR, Caracu; GI, Gir; GZ, Guzerat; HO, Holstein; IN, Indo-Brazilian; JE, Jersey; NE, Nelore; NO, Polled Nelore; SD, Sindhi. 
Allele frequencies for each microsatellite locus in 15 representative Nelore herds are depicted in Figure 1. A total of 95 alleles were detected across all loci, yielding a mean value of 10.5 alleles per locus; low variability was verified in BM1824 (7 alleles) and ETH10 (8 alleles), and the highest variability was found in TGLA122, with 17 alleles (data not shown). The analysis of each microsatellite locus taken alone (data not shown) showed that BM2113, TGLA122 and TGLA126 loci had PIC values higher than 50\% in all Nelore herds. TGLA122 and TGLA126 loci showed the highest PIC values, with minimum values of 67.26 and $54.6 \%$ and maximum values of 86.5 and $77.4 \%$, respectively. TGLA227 locus showed the lowest observed heterozygosity $(\mathrm{He})(0.123$ to 0.819$)$ and PIC values $(0.116$ to 0.708$)$ across all Nelore herds.
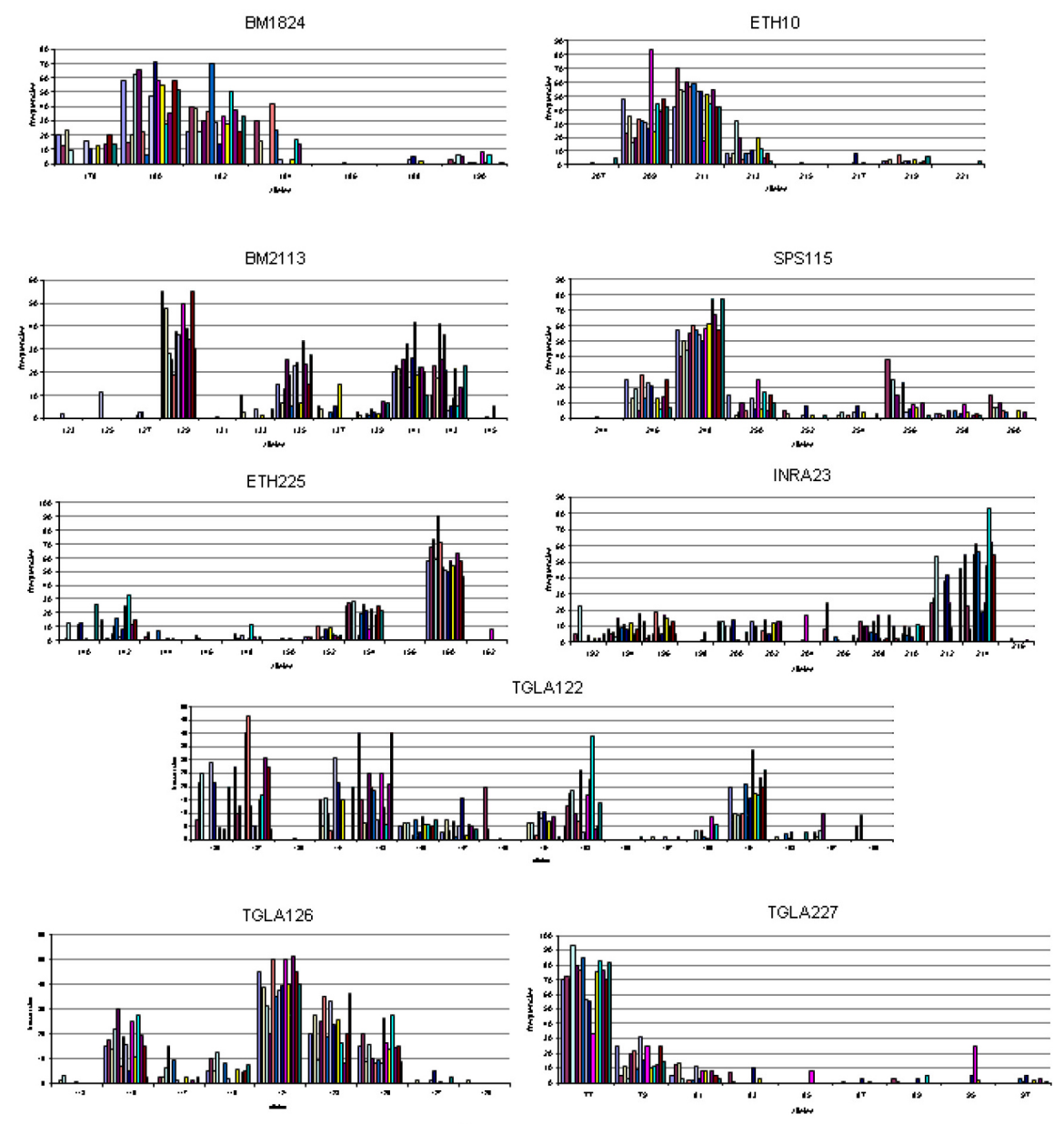

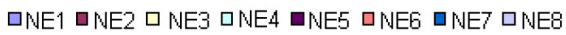

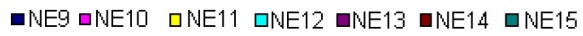

Figure 1. Allele frequencies of 9 microsatellites of the ISAG panel in 615 bovine animals from 15 Nelore herds (NE1 to NE15). Alleles for each locus are numbered from the shorter to the larger allele in 2-bp size intervals, following the ISAG nomenclature. 
Detailed population statistics for each Nelore herd are shown in Table 2. The mean number of alleles per microsatellite locus varied from 4.00 to 9.11 across all herds. PIC values were greater than $50 \%$ in all 15 herds analyzed. Gene diversity values ranged from 0.589 to 0.705 and He from 0.593 to 0.672 . Global mean heterozygosity and PIC indicated high diversity in Nelore cattle herds (mean $\mathrm{He}=0.63$; mean $\mathrm{PIC}=0.58$ ).

Table 2. Sample size, mean number of alleles per locus (MNA), gene diversity (GD), observed heterozygosity (He), and polymorphism information content (PIC) for each of 15 Nelore herds.

\begin{tabular}{|c|c|c|c|c|c|}
\hline Population & Sample size & MNA & GD & $\mathrm{He}$ & PIC \\
\hline NE1 & 20 & 4.33 & 0.625 & 0.600 & 0.554 \\
\hline NE2 & 20 & 6.11 & 0.684 & 0.672 & 0.626 \\
\hline NE3 & 40 & 7.56 & 0.676 & 0.642 & 0.629 \\
\hline NE4 & 16 & 5.00 & 0.633 & 0.646 & 0.571 \\
\hline NE5 & 10 & 4.22 & 0.599 & 0.611 & 0.527 \\
\hline NE6 & 30 & 5.00 & 0.591 & 0.630 & 0.529 \\
\hline NE7 & 48 & 5.89 & 0.614 & 0.606 & 0.567 \\
\hline NE8 & 257 & 9.11 & 0.694 & 0.633 & 0.649 \\
\hline NE9 & 19 & 6.44 & 0.705 & 0.626 & 0.651 \\
\hline NE10 & 6 & 4.00 & 0.670 & 0.593 & 0.561 \\
\hline NE11 & 60 & 7.44 & 0.671 & 0.628 & 0.630 \\
\hline NE12 & 9 & 4.00 & 0.589 & 0.667 & 0.509 \\
\hline NE13 & 41 & 5.78 & 0.619 & 0.610 & 0.569 \\
\hline NE14 & 20 & 4.33 & 0.625 & 0.600 & 0.554 \\
\hline NE15 & 40 & 6.22 & 0.632 & 0.664 & 0.581 \\
\hline Mean & & 5.70 & 0.64 & 0.63 & 0.58 \\
\hline
\end{tabular}

Population differentiation among the 15 Nelore herds was estimated by Wright fixation indexes, Fit, Fst and Fis, for each of the 9 microsatellite loci (Table 3). The mean heterozygote deficit (Fit) was 7.94\%. The genetic differentiation among herds (Fst) was moderate (8.4\%). The highest Fst values were found for INRA23 (15.95\%) and BM1824 (11.82\%). There was a mean heterozygote deficit (Fis) of $-0.50 \%$ (meaning "outbreeding"). Gene flow values (Nm) ranged from 1.31 (INRA23) to 6.49 (TGLA126) with a mean value of 2.72 .

Table 3. Summary of F-statistics and gene flow for each of 9 microsatellite loci in 15 Nelore herds.

\begin{tabular}{lcccc}
\hline Locus & Fis & Fit & Fst & Nm* \\
\hline BM1824 & 0.0810 & 0.1897 & 0.1182 & 1.8648 \\
BM2113 & -0.0087 & 0.0465 & 0.0547 & 4.3237 \\
ETH10 & -0.0922 & -0.0100 & 0.0753 & 3.0694 \\
ETH225 & -0.0009 & 0.0646 & 0.0655 & 3.5692 \\
INRA23 & 0.0368 & 0.1905 & 0.1595 & 1.3173 \\
SPS115 & 0.0297 & 0.0907 & 0.0629 & 3.7259 \\
TGLA122 & -0.0304 & 0.0623 & 0.0900 & 2.5287 \\
TGLA126 & -0.0605 & -0.0211 & 0.0371 & 6.4886 \\
TGLA227 & 0.0106 & 0.0859 & 0.0761 & 3.0341 \\
Mean & -0.0050 & 0.0794 & 0.0840 & 2.7250 \\
\hline
\end{tabular}

$\mathrm{Nm}=$ gene flow estimated from Fst $=0.25(1-$ Fst $) /$ Fst.

The dendrogram generated by the matrix of $\mathrm{D}_{\mathrm{A}}$ (genetic distance) among the different Nelore herds and the other zebu, taurine and synthetic breeds is shown in Figure 2. This dendrogram shows at least two main clusters: I) the (mainly) zebu cluster and II) the (mainly) 
taurine cluster. The zebu cluster comprises at least three sub-clusters: sub-clusters I.1 and I.2, featuring different Nelore/Polled Nelore herds and sub-cluster I.3, featuring Brahman, Guzerat, Gir, Indo-Brazilian, and Sindhi. Santa Gertrudis appears in the dendrogram as the best example of a synthetic zebu-European cattle breed, followed by Tabapuã.

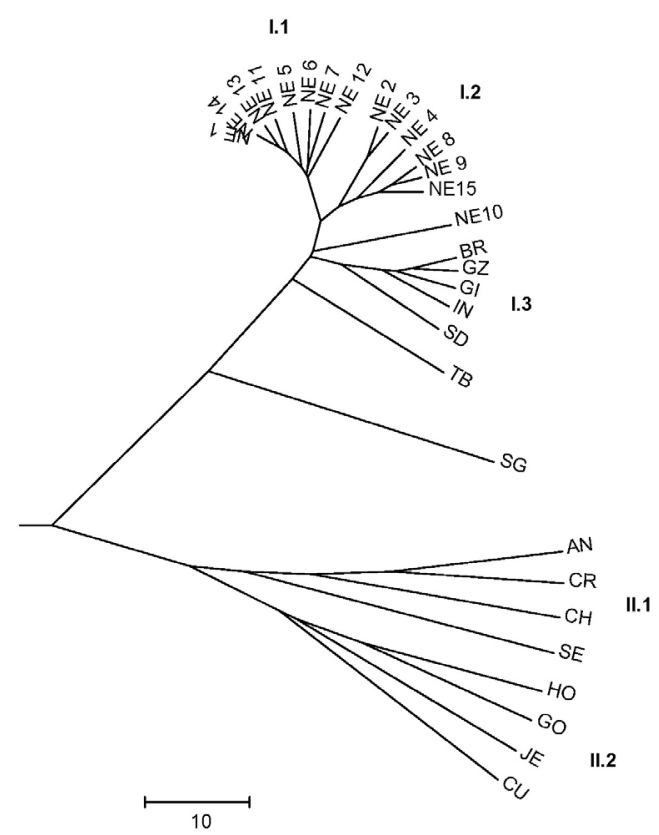

Figure 2. Dendrogram of genetic relationship among 1543 bovine animals. This neighbor-joining dendrogram depicts the Nelore herds (NE1 to NE15) and other zebu, synthetic and taurine breeds raised in Brazil. JE, Jersey; CU, Curraleiro; GO, Girolando (Gir-Holstein); HO, Holstein; SE, Senepol; CH, Charolais; AN, Angus; CR, Caracu; SG, Santa Gertrudis; SD, Sindhi; IN, Indo-Brazilian; GI, Gir; GZ, Guzerat; BR, Brahman; TB, Tabapuã. NE12 and NE10 are Polled Nelore herds. NE2 and NE3 are state-owned herds selected over 30 years for higher post-weaning weight gain, from a common ancestral population represented by NE1 (control herd). Main clusters are: I) the (mainly) zebu cluster and II) the (mainly) taurine cluster. The zebu cluster comprises at least three sub-clusters: subcluster I.1, featuring the "thrifty" NE; sub-cluster I.2, featuring the "demanding" NE and sub-cluster I.3, featuring $\mathrm{SD}, \mathrm{IN}, \mathrm{GI}, \mathrm{GZ}$, and BR. SG appears in the dendrogram as the best example of a synthetic zebu-European cattle breed, followed by TB. The taurine cluster has two sub-clusters: sub-cluster II.1, featuring AN, CR, CH, and SE and sub-cluster II.2, featuring HO, GO, JE, and CU. Note higher genetic differentiation/genetic distance among European breeds, than among zebu breeds. See text for the meaning of the terms "thrifty" and "demanding", as used here, and the experimental paradigm supporting this classification.

\section{DISCUSSION}

Our data show that genetic differentiation was greater among taurine cattle than among zebu cattle raised in Brazil. Conversely, gene flow was higher among zebu than among taurine cattle, as illustrated by Figure 1, which shows a relatively high variation in allele frequencies of 9 microsatellite markers among 15 Nelore herds.

Population pairwise Fst and $\mathrm{Nm}$ (gene flow) results were consistent with the dendrogram based on genetic distance (Figure 2). Nm and Fst values for Nelore x Polled Nelore were 18.2639 
and 0.0135 , respectively. $\mathrm{Nm}$ values higher than 4.0 indicate that populations are a panmitic unit (Kimura and Maruyama, 1971). Accordingly, Nm and Fst values, genetic distance analyses and the dendrogram (Figure 2) indicate that Nelore and Polled Nelore populations are a panmitic unit. These results are consistent with the history of the formation of Polled Nelore, which was considered by the Brazilian genealogic registry as a separate breed beginning in 1999, although breeding among Nelore and Polled Nelore still goes on in most farms in Brazil.

Figure 2 shows that Brahman and Guzerat populations are closely related and form a sister group with Gir. These findings are corroborated by the Nm and Fst values of 4.0553 and 0.0175 , respectively, obtained between Brahman x Guzerat, confirming the genetic similarity between the two populations. Similar results can be observed comparing Brahman, Guzerat, and Gir populations, indicating that Brahman populations have high genetic similarity with Guzerat and Gir. These results are in line with the history of the Brahman breed. The formation of the breed dates back to 1915, in the USA; the breed resulted from mating programs involving Guzerat, Gir and Brazilian Nelore, with a predominance of Guzerat.

Fst and Nm values (Table 3) and the dendrogram (Figure 2) showed a close relationship between Indo-Brazilian and Gir. This finding is in line with the general assumption that the IndoBrazilian breed was formed by mating Guzerat to Nelore, followed by Gir (Santiago, 1985).

In passing, we found a strong relationship between the original geographic distribution of zebu breeds in India and genetic distance of breeds in sub-cluster I.3 (Figure 2), especially as it relates to the exquisite cattle from the northwestern region of India (Figure 3).

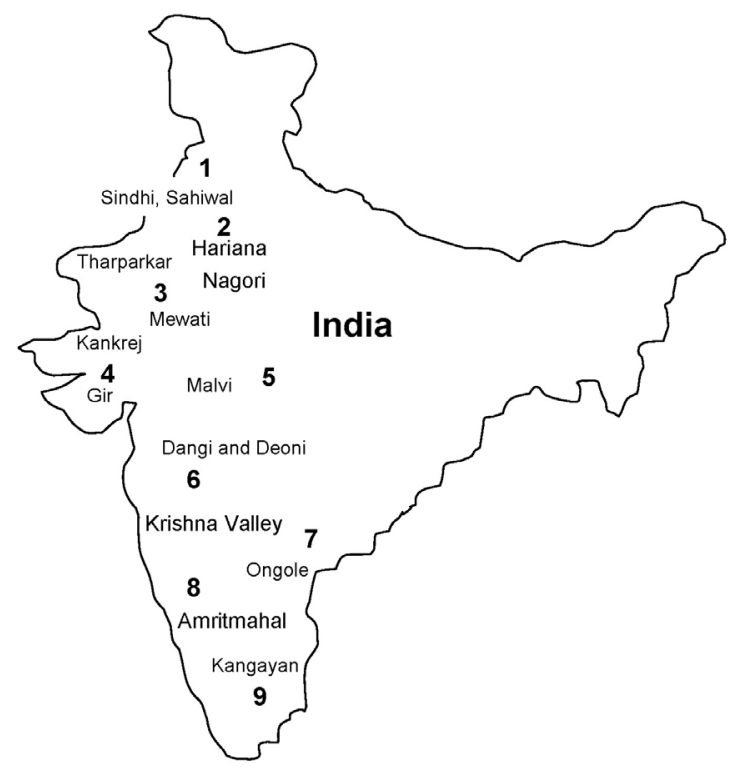

Figure 3. Map of India showing the distribution of some breeds of cattle as related to the following selected regions: 1, Punjab; 2, Arunachal Pradesh; 3, Rajastan; 4, Guzerat; 5, Madhya Pradesh; 6, Maharashtra; 7, Andhra Pradesh; 8, Karnataka; 9, Tamil Nadu. White-coated, small-eared, Nelore-like cattle have a widespread distribution, ranging from the northwestern regions (Tharparkar, Hariana, Nagori, Mewati, and Malvi, among other cattle) to the southern regions (Ongole, Krishna Valley, Kangayan, and Amritmahal, among other cattle). Exquisite cattle, such as the red-coated Gir and Sindhi and the large-horned Kankrej have a more discrete geographic distribution. 
More complex relationships arise in the analysis of sub-clusters I.1 and I.2. A possible explanation is a phenotype bias, "white coat, short ears" being features common to many Nelore-like cattle, which are actually different cattle from regions quite apart from each other in India, such as northwestern India (e.g., Tharparkar, Hariana, Nagori, Mewati, and Malvi cattle) and southern India (e.g., Ongole, Krishna Valley, Kangayan, and Amritmahal cattle). We realize that white-coated, short-eared cattle have frequently been regarded as Nelore cattle by breeders in Brazil, regardless of their different geographic origins in India or their diverse genetic background. As a result, traditional selection based on phenotype alone, and outbreeding are likely to have contributed to a significant melting among these different cattle during decades. Future studies shall unveil the contributions of these Nelore-like cattle to the formation of the Brazilian Nelore.

\section{An attempt at a classification of Nelore cattle}

The genetic diversity of Brazilian Nelore cattle notwithstanding, and taking advantage of our own field experience in genotype-phenotype associations, we propose a classification of cattle in sub-clusters I.1 and I.2 that could have some bearing on the metabolic strategies of adaptation to diverse ecological settings. According to this classification, sub-cluster I.1 encompasses mainly small-framed, "thrifty" Nelore-like cattle, whereas sub-cluster I.2 includes large-framed, more "demanding" Nelore-like cattle. It is noteworthy that some white-coated, Nelore-like cattle were naturally selected in more exacting environments such as those found in northwestern India. This is the case of Tharparkar, Hariana, Nagori, Mewati, and Malvi cattle. Their exacting environments would have selected for the "thrifty" phenotype. Conversely, more favorable environments such as those found in southern India would have selected for more demanding phenotypes, of which the large-framed, all day active, draught-type Ongole, Krishna Valley, Kangayan and Amritmahal cattle are good examples.

An experimental paradigm supporting this classification is given by the genetic differentiation of an ancestral population of sub-cluster I.1 (represented by NE1, the "control herd") into two daughter-populations or "selection herds", NE2 and NE3, grouped in sub-cluster I.2 (Figure 2). These are state-owned herds selected for enhanced post-weaning weight gain during the last 30 years of selection and directed breeding at the Sertãozinho Experimental Station (Razook et al., 2002). Recorded average frames have grown accordingly larger in the selection herds NE2 and NE3, as compared to the control herd NE1, and as a result, selected and control herds have segregated into two different sub-clusters.

The genetic diversity of the most important Brazilian beef cattle imposes the use of marker-assisted selection (MAS) as a tool for selection and breeding. MAS shall help breeders in the formation of more standardized, industry-oriented, parental lines of Nelore cattle. Gene flow and gene segregation in a polymorphic zebu population constitute major drawbacks to industry-oriented selection of cattle in Brazil, because these phenomena foster random variability, instead of standardization. There is thus good reason to believe that the use of MAS will accelerate industry-oriented selection of zebu cattle in Brazil at a relatively higher rate than can be expected for taurine cattle.

\section{CONCLUSION}

Genetic differentiation was found to be higher in taurine than in zebu cattle raised in 
Brazil. Nelore cattle, which constitute the most conspicuous zebu herds raised in Brazil, are more genetically variable than one could suppose solely based on phenotype analysis. We identified two major groups of Nelore cattle raised in Brazil, based on genetic marker analysis.

\section{ACKNOWLEDGMENTS}

We acknowledge the technical assistance of the Excegen's staff: Felipe Teles, in computer analyses and Cecilia Trancoso, Denise Vieira, Lucinea Souza, and Elisangela Monteiro, in the preparation of samples. We are most thankful to the Brazilian cattle breeders and their technical staff who provided samples used in this study. We are indebted to Dr. Fausto Pereira Lima for suggestions and critiques and Dr. Alexander George Razook for kindly reviewing the manuscript. Research supported by Acangaú Foundation, CNPq, FAPEMIG, FAPESP, and SEBRAE.

\section{REFERENCES}

Archibald AL, Haley CS, Brown JF, Couperwhite S, et al. (1995). The PiGMaP consortium linkage map of the pig (Sus scrofa). Mamm. Genome 6: 157-175.

Bishop MD, Kappes SM, Keele JW, Stone RT, et al. (1994). A genetic linkage map for cattle. Genetics 136: 619-639.

Bowcock AM, Ruiz-Linares A, Tomfohrde J, Minch E, et al. (1994). High resolution of human evolutionary trees with polymorphic microsatellites. Nature 368: 455-457.

Bruford MW and Wayne RK (1993). Microsatellites and their application to population genetic studies. Curr. Opin. Genet. Dev. 3: 939-943

Carneiro GG (1954). The bull test in dairy herds under penkeeping system. Arq. Esc. Sup. Vet. UREMG 7: 53-65.

Carneiro GG and Lush JL (1948). Variations in yield of milk under the penkeeping system in Brazil. J. Dairy Sci. 31: 203-211.

Carneiro GG and Memória JPM (1959). Preliminary study on the Zebu bull progeny test. Arq. Esc. Sup. Vet. UREMG 12: 415-424.

Cervini M, Henrique-Silva F, Mortari N and Matheucci E Jr (2006). Genetic variability of 10 microsatellite markers in the characterization of Brazilian Nellore cattle (Bos indicus). Genet. Mol. Biol. 29: 486-490.

Cheng HH, Levin I, Vallejo RL, Khatib H, et al. (1995). Development of a genetic map of the chicken with markers of high utility. Poult. Sci. 74: 1855-1874.

Egito AA, Paiva SR, Albuquerque MS, Mariante AS, et al. (2007). Microsatellite based genetic diversity and relationships among ten Creole and commercial cattle breeds raised in Brazil. BMC. Genet. 8: 83.

Forbes SH, Hogg JT, Buchanan FC, Crawford AM, et al. (1995). Microsatellite evolution in congeneric mammals: domestic and bighorn sheep. Mol. Biol. Evol. 12: 1106-1113.

Glowatzki-Mullis ML, Gaillard C, Wigger G and Fries R (1995). Microsatellite-based parentage control in cattle. Anim. Genet. 26: 7-12.

Hazan J, Dubay C, Pankowiak MP, Becuwe N, et al. (1992). A genetic linkage map of human chromosome 20 composed entirely of microsatellite markers. Genomics 12: 183-189.

IBGE (Instituto Brasileiro de Geografia e Estatística) (2005). Banco de dados agregados; efetivos/rebanhos. [http://www. sidra.ibge.gov.br/bda/pecua/default.asp]. Accessed May 7, 2008.

Jaeger LG (1943). Separata da Revista do Instituto Histórico e Geográfico do Rio Grande do Sul, II Trimestre de 1943, Ano XXIII. In: História da Introdução do Gado no Rio Grande do Sul (1634). Ofício Gráfico da Imprensa Oficial, Porto Alegre, 127-245.

Jeffreys AJ, Allen MJ, Hagelberg E and Sonnberg A (1992). Identification of the skeletal remains of Josef Mengele by DNA analysis. Forensic Sci. Int. 56: 65-76.

Kemenes PA, Regitano LCA, Rosa AJM, Packer IU, et al. (1999). $\kappa$-Casein, $\beta$-lactoglobulin and growth hormone allele frequencies and genetic distances in Nelore, Gyr, Guzerá, Caracu, Charolais, Canchim and Santa Gertrudis cattle. Genet. Mol. Biol. 22: 539-541.

Kimura M and Maruyama T (1971). Pattern of neutral polymorphism in a geographically structured population. Genet. Res. 18: 125-131. 
Machado MA, Schuster I, Martinez ML and Campos AL (2003). Genetic diversity of four cattle breeds using microsatellite markers. R. Bras. Zootec. 32: 93-98.

MacHugh DE, Loftus RT, Bradley DG, Sharp PM, et al. (1994). Microsatellite DNA variation within and among European cattle breeds. Proc. Biol. Sci. 256: 25-31.

MacHugh DE, Shriver MD, Loftus RT, Cunningham P, et al. (1997). Microsatellite DNA variation and the evolution, domestication and phylogeography of taurine and zebu cattle (Bos taurus and Bos indicus). Genetics 146: 1071-1086.

Meirelles FV, Rosa AJM, Lôbo RB, Garcia JM, et al. (1999). Is the American zebu really Bos indicus? Genet. Mol. Biol. 22: $543-546$.

Memória JPM (1954). Selection differential and genetic gain. Arq. Esc. Sup. Vet. UREMG 7: 67-70.

Miretti MM, Pereira HA Jr, Poli MA, Contel EP, et al. (2002). African-derived mitochondria in South American native cattle breeds (Bos taurus): evidence of a new taurine mitochondrial lineage. J. Hered. 93: 323-330.

Razook AG, Figueiredo LA, Bonilha Neto LM, Cyrillo JN dos SG, et al. (2002). The Role of the Experimental Station of Sertãozinho (SP) - Brazil in the Preservation and Selection of Zebu Breeds and Caracu. In: World Congress on Genetics Applied to Livestock Production CD ROM - Sustainable breeding plans in developed countries (No. 24-05), Montpellier, France.

Rouse JE (1977). The Criollo: Spanish cattle in the Americas. University of Oklahoma Press, Norman.

Salazar J and Cardozo A (1986). Desarrollo del Ganado Criollo en América Latina: Resumen Histórico y Distribución Actual. In: Ganado Bovino Criollo Orientación Gráfica, Buenos Aires, 164-169.

Santiago AA (1985). O Zebu na Índia, no Brasil e no Mundo. Instituto Campineiro de Ensino Agrícola, Campinas.

Tundisi AGA, Lima FP, Kalil EB, Villares JB, et al. (1965/1966). Interpretação sobre a eficiência das provas de ganho de peso e a viabilidade da produção econômica de novilhos zebus próxima dos 24 meses de idade. Boletim de Indústria Animal, Nova Odessa, 23: 67-81.

Villares JB (1950). Climatologia zootecnia IX. Aspectos da produção de carne em certas zonas tropicais. Rev. Criadores 2: $39-52$.

Yeh FC and Boyle TJB (1997). Population genetic analysis of co-dominant and dominant markers and quantitative traits. Belg. J. Bot. 129: 156-159. 